\title{
Is the red spotted green frog Hypsiboas punctatus (Anura: Hylidae) selecting its preys? The importance of prey availability
}

\author{
Javier A. López ${ }^{1,2}$, Pablo A. Scarabotti ${ }^{1,2}$, María C. Medrano ${ }^{3}$ \& Romina Ghirardi ${ }^{1,4}$ \\ 1. Instituto Nacional de Limnología (CONICET - UNL), Ciudad Universitaria "Paraje El Pozo", (3000) Santa Fe, pro- \\ vincia de Santa Fe, Argentina; yojalg@gmail.com, pascarabotti@yahoo.com.ar, romighirardi@yahoo.com.ar \\ 2. Universidad Autónoma de Entre Ríos, Facultad de Ciencia y Tecnología, Andrés Pazos y Corrientes, (3100), Paraná, \\ provincia de Entre Ríos, Argentina \\ 3. Museo Provincial de Ciencias Naturales "Florentino Ameghino", Primera Junta 2859, (3000) Santa Fe, provincia de \\ Santa Fe, Argentina; celestazo@hotmail.com \\ 4. Instituto de Botánica Carlos Spegazzini, Avenida 53 No. 477, (1900) La Plata, provincia de Buenos Aires, Argentina.
}

$$
\text { Received 19-VI-2008. Corrected 22-II-2009. Accepted 25-III-2009. }
$$

\begin{abstract}
The study of the feeding ecology of amphibians is an old issue in herpetology. Notwithstanding, the lack of food resources data in many studies of amphibians feeding has lead to partial understanding of frog feeding strategies. In this study we evaluate the trophic selectivity of a red spotted green frog (Hypsiboas punctatus) population from a Middle Paraná River floodplain pond in Argentina, and discuss the importance of prey availability data when interpreting results from diet analysis. We analyzed the gut contents of $47 \mathrm{H}$. punctatus adults and compared frog's diet with the environmental food resources. Prey availability was estimated by systematically seep-netting the microhabitat where anurans were localized foraging. We identified 33 taxonomic categories from gastrointestinal contents. Numerically, the most important prey categories were dipterans, followed by hemipterans, homopterans and coleopterans. The diet similarity between males and females was high and no statistical differences in diet composition were found. The most abundant food resources in the environment were dipterans, coleopterans, homopterans and collembolans. In order to assess whether frogs were selecting their preys, we calculated Pianka's niche overlap index and Jacobs' electivity index comparing gut contents to prey availability data. Trophic niche overlap was medium but significantly higher than expected by chance. The electivity index indicated that $H$. punctatus foraged dipterans slightly above their environmental abundance. Among the secondary preys, hemipterans were foraged selectively, homopterans were consumed in the same proportion to their occurrence in the environment, coleopterans were foraged quite under their availability and collembolans were practically ignored by frogs. Without food resources data, H. punctatus could be classified as a specialist feeder, but dipterans also were quite abundant in the environment. Our results show that $H$. punctatus fit better as a generalist feeder, foraging on their main food item and some secondary preys in similar proportion to their environmental availability; even though other secondary preys are being selectively preferred or ignored by frogs. Our data illustrate the importance of including the resource availability data on diet studies to improve the understanding of amphibian feeding ecology. Rev. Biol. Trop. 57 (3): 847-857. Epub 2009 September 30.
\end{abstract}

Key words: Hypsiboas punctatus, trophic selectivity, food resources, diet, anuran.

Historically, amphibian feeding ecology analysis has been carried out based on taxonomic identification of gut contents (Frost 1935, Klimstra \& Meyers 1965, Lajmanovich 1995, Caldwell \& Vitt 1999, Parmelee 1999, Maneyro et al. 2004, López et al. 2005b). On this basis, amphibians have been classified as active or passive ("sit and wait") foragers, and specialist, intermediate or generalist predators (Toft 1980, Simon 1982, Lieberman 1986, Simon \& Toft 1991, Duellman \& Lizana 1994, López et al. 2003, Lajmanovich 1996, Hirai \& Matsui 2000a) depending on relative proportions of the different type of prey found in their 
gastrointestinal tracts and trophic niche amplitude. Moreover, feeding strategies of this group can show a wide variation when prey differing in quality and abundance, either temporally or spatially, are available (Burton 1976, Krebs 1978, López et al. 2005a).

Foraging selectivity is usually defined as any significant deviation in predator diet compared to prey samples taken from habitat used by the predator (Stephens \& Krebs 1986). Many factors contribute to selectivity but prey body size is often considered a major determinant (Krebs 1978, Stephens \& Krebs 1986). Although feeding habits are an old subject in amphibian natural history studies (Frost 1924, 1935, Hamilton 1930, 1948, Cott 1932, 1934, Korschgen \& Moyle 1955), the analysis of environmental prey availability for a better understanding of feeding ecology of this group was recently incorporated on batrachological studies (Hirai \& Matsui 2000b, 2001a, Isacch \& Barg 2002, Hirai 2004, López et al. 2007).

Hypsiboas punctatus is a widely distributed Neotropical hylid frog (total range area $=$ $11306927 \mathrm{~km}^{2}$ ). This species occurs throughout the Amazon basin in South America, south to the Chaco region of Paraguay and along the banks of the Paraguay-Paraná Rivers in Argentina. It is also present on Trinidad Island, in Trinidad and Tobago (IUCN 2006). On the Paraná River floodplain, $H$. punctatus is usually found calling in lagoons on aquatic grasses, cyperaceous and floating mats of water hyacinth (Eichhornia crassipes) and floating primrose-willow (Ludwigia peploides). These environments have a rich trophic offer to amphibians, based on abundant insects and other arthropods. Although Gallardo \& Varela de Olmedo (1992) discussed some aspects of the ecology of $H$. punctatus, there is only one analysis of the diet of this frog for the Paraná River environments (López et al. 2002). In this short communication, López et al. (2002) reported a high proportion of dipterans (over $50 \%$ ) in $H$. punctatus gut contents but suggested a "sit and wait" foraging behaviour for this species without assessing frogs food selection.
The purpose of this study is to describe the diet, compare it to the environmental food resources, and evaluate the trophic selectivity of a $H$. punctatus population inhabiting a fluvial pond of middle Paraná River in Argentina.

\section{MATERIALS AND METHODS}

Study site: Sampling was conducted on an alluvial pond of the vast Paraná River floodplain system $\left(38000 \mathrm{~km}^{2}\right.$, Neiff 2001$)$, at Sirgandero Island ( $31^{\circ} 38^{\prime} \mathrm{S}, 60^{\circ} 40^{\prime} \mathrm{W}, 2300 \mathrm{ha}$ approximately), near Santa Fe city (Santa Fe province, Argentina). The Paraná River has a complex system of islands, sand bars, tributaries, branches, marshes and ponds, connected at different degrees with the main channel (Neiff 2001, Drago et al. 2003). The warmer months are September to February, with a mean annual temperature of $18 \pm 1{ }^{\circ} \mathrm{C}$. Average annual precipitations are slightly below $1000 \mathrm{~mm}$ and rainfalls concentrates in summer season. The sampled pond was covered by floating mats of water hyacinth (E. crassipes) and floating primrose-willow (L. peploides). Surroundings were characterized by tall grass wetlands and hydrophilous forests (assemblages of Salix humboldtiana, Tessaria integrifolia, Enterolobium contortisiliquum and Erithrina crista-galli).

Diet analysis: In April 2004 we collected $47 \mathrm{H}$. punctatus adults (snout-vent length: males, mean $=25.9 \mathrm{~mm}, \mathrm{SD}=1.91, \mathrm{~N}=6$; females, mean=26.1mm, $\mathrm{SD}=1.9, \mathrm{~N}=41$ ) within two hours after sunset. Specimens were deposited in the herpetological collection of the Instituto Nacional de Limnología (INALI-CONICETUNL, Santa Fé, Argentina) (Catalog numbers: INALI-HP-1 to INALI-HP-47). In order to determine frogs' diet, digestive tracts contents were analyzed under a stereoscopic dissecting microscope. Each prey was identified to the lowest possible taxonomic level (usually family) and measured using a $0.01 \mathrm{~mm}$ precision digital caliper (length and wide at the broader portion of the body). We counted as individuals only preys that still evidenced key structures for identification (heads, elytra, jaws, and the 
like). Volume for each order of prey item was estimated using the ellipsoid formula (see Dunham 1983). For each taxon, frequency of occurrence (FO) was calculated according to the formula of Lescure (1971). Most papers on feeding ecology use prey number $(\mathrm{N})$, volume (V), or frequency of occurrence separately to analyze frog diet. In this work we calculated values of the relative importance index (IRI) (Pinkas et al. 1971) that combine the three measurements mentioned above to determine each prey category contribution to the diet (Lajmanovich 1995). As this index gives a value with no maximum limit, we transformed quantitative results into percentages (IRI\%) to allow an easier interpretation (López et al. 2007).

Food resources samples: Arthropods abundances were estimated by entomological sweep-net sampling (Hirai \& Matsui 2000a, 2001b). Netting was carried out in two sevenminutes zigzag transects through $H$. punctatus foraging microhabitats at the same night in which frogs were manually captured. Data of the two sweep-net transects were combined for the analysis.

Trophic selectivity analysis: We evaluated diet composition similarity between males and females with Pianka's niche overlap index
$\left(\mathrm{O}_{\mathrm{jk}}\right)$ and Chi Square test (López et al. 2005b). Pianka's niche overlap index (Pianka 1974) also was used to compare the diet of frogs with environmental prey availability. To determine whether measured overlap and Chi Square values differed from what would be expected by chance, we performed a randomization analysis through the EcoSim software (Gotelli \& Entsminger 2003). EcoSim performs Monte Carlo randomizations to create "pseudo-communities" (Pianka 1986), and then statistically compares the patterns in these randomized communities with those in the real data matrix. In this analysis, the values of the original matrix were randomized 1000 times and the niche breadth was retained. We also calculated Jacobs' selectivity index (D) and compared the results for the more abundant arthropods in the environment and frogs' gut contents (Jacobs 1974). Additionally, we tested the differences in relative abundances of the more important preys between environment and frogs' diet with a Z Test (Filipello \& Crespo 1994, Sokal \& Rohlf 1995).

\section{RESULTS}

The most abundant prey on gut contents were also the most important diet items following IRI values (Table 1). From the 33 prey items determined in the frog diet, dipterans

TABLE 1

Comparison between $\mathrm{H}$. punctatus diet and environmental food resources

\begin{tabular}{|c|c|c|c|c|c|c|}
\hline \multirow{2}{*}{ Prey categories } & \multicolumn{3}{|c|}{ Frogs' diet } & \multirow{2}{*}{$\begin{array}{l}\text { Food availability } \\
\text { N }\end{array}$} & \multicolumn{2}{|c|}{ Jacobs' index } \\
\hline & $\mathrm{N}$ & $\mathrm{FO}$ & IRI\% & & $\mathrm{D}$ & orders' D \\
\hline Insecta & 198 & & 96.43 & 3788 & & \\
\hline Protura & & & & 1 & & -1 \\
\hline Protura n.i. & & & & 1 & -1 & \\
\hline Collembola & 2 & & 0.16 & 494 & & -0.87 \\
\hline Poduridae & & & & 6 & -1 & \\
\hline Entomobryidae & 2 & 2 & 0.16 & 429 & -0.85 & \\
\hline Sminthuridae & & & & 59 & -1 & \\
\hline Orthoptera & 2 & & 2.23 & 207 & & -0.70 \\
\hline Orthoptera n.i. & 2 & 2 & 2.23 & 4 & 0.81 & \\
\hline
\end{tabular}


TABLE 1 (Continued)

Comparison between $\mathrm{H}$. punctatus diet and environmental food resources

\begin{tabular}{|c|c|c|c|c|c|c|}
\hline \multirow{2}{*}{ Prey categories } & \multicolumn{3}{|c|}{ Frogs' diet } & \multirow{2}{*}{$\begin{array}{c}\text { Food availability } \\
\text { N }\end{array}$} & \multicolumn{2}{|c|}{ Jacobs' index } \\
\hline & $\mathrm{N}$ & FO & IRI\% & & $\mathrm{D}$ & orders' D \\
\hline Gryllidae & & & & 132 & -1 & \\
\hline Tettigonidae & & & & 38 & -1 & \\
\hline Acrididae & & & & 32 & -1 & \\
\hline Paulinidae & & & & 1 & -1 & \\
\hline Blattaria & & & & 1 & & -1 \\
\hline Blattaria n.i. & & & & 1 & -1 & \\
\hline Thysanoptera & & & & 245 & & -1 \\
\hline Thysanoptera n.i. & & & & 245 & -1 & \\
\hline Trichoptera & 4 & & 0.38 & & & \\
\hline Trichoptera n.i. & 4 & 2 & 0.38 & & 1 & 1 \\
\hline Hemiptera & 47 & & 30.07 & 136 & & 0.78 \\
\hline Hemiptera n.i. & 8 & 5 & 6.82 & 68 & 0.40 & \\
\hline Pyrrhocoridae & & & & 4 & -1 & \\
\hline Coreidae & & & & 3 & -1 & \\
\hline Pentatomidae & 1 & 1 & 0.69 & 8 & 0.41 & \\
\hline Reduviidae & & & & 1 & -1 & \\
\hline Lygaeidae & 38 & 15 & 22.56 & 11 & 0.98 & \\
\hline Nabidae & & & & 9 & -1 & \\
\hline Hydrometridae & & & & 1 & -1 & \\
\hline Belostomatidae & & & & 1 & -1 & \\
\hline Miridae & & & & 23 & -1 & \\
\hline Anthocoridae & & & & 7 & -1 & \\
\hline Homoptera & 29 & & 18.33 & 504 & & 0.06 \\
\hline Homoptera n.i. & 17 & 12 & 11.43 & 22 & 0.88 & \\
\hline Cicadellidae & 6 & 5 & 4.18 & 253 & -0.39 & \\
\hline Cercopidae & 5 & 5 & 2.68 & 70 & 0.16 & \\
\hline Aleyrodidae & & & & 2 & -1 & \\
\hline Psyllidae & & & & 113 & -1 & \\
\hline Aphididae & & & & 27 & -1 & \\
\hline Membracidae & 1 & 1 & 0.04 & 17 & 0.06 & \\
\hline Odonata & 1 & & 0.98 & 18 & & 0.03 \\
\hline Odonata n.i. & & & & 8 & -1 & \\
\hline Coenagrionidae & 1 & 1 & 0.98 & 10 & 0.32 & \\
\hline Neuroptera & & & & 2 & & -1 \\
\hline Neuroptera n.i. & & & & 2 & -1 & \\
\hline Lepidoptera & 1 & & 1.58 & 28 & & -0.19 \\
\hline Lepidoptera n.i. & 1 & 1 & 1.58 & 28 & -0.19 & \\
\hline
\end{tabular}


TABLE 1 (Continued)

Comparison between $\mathrm{H}$. punctatus diet and environmental food resources

\begin{tabular}{|c|c|c|c|c|c|c|}
\hline \multirow{2}{*}{ Prey categories } & \multicolumn{3}{|c|}{ Frogs' diet } & \multirow{2}{*}{$\begin{array}{c}\text { Food availability } \\
\text { N }\end{array}$} & \multicolumn{2}{|c|}{ Jacobs' index } \\
\hline & $\mathrm{N}$ & $\mathrm{FO}$ & IRI\% & & $\mathrm{D}$ & orders' D \\
\hline Coleoptera & 18 & & 3.52 & 637 & & -0.33 \\
\hline Coleoptera n.i. & 3 & 3 & 0.38 & 44 & 0.14 & \\
\hline Carabidae & & & & 23 & -1 & \\
\hline Scolytidae & & & & 3 & -1 & \\
\hline Dytiscidae & & & & 20 & -1 & \\
\hline Hydrophilidae & & & & 26 & -1 & \\
\hline Staphilinidae & 2 & 1 & 0.09 & 15 & 0.44 & \\
\hline Pselaphidae & 1 & 1 & 0.05 & 37 & -0.32 & \\
\hline Elateridae & 2 & 2 & 0.17 & 7 & 0.69 & \\
\hline Scarabaeidae & 2 & 2 & 0.49 & 9 & 0.62 & \\
\hline Heteroceridae & & & & 4 & -1 & \\
\hline Coccinelidae & 1 & 1 & 0.85 & 17 & 0.06 & \\
\hline Chrysomelidae & 7 & 4 & 1.49 & 270 & -0.35 & \\
\hline Curculionidae & & & & 162 & -1 & \\
\hline Hymenoptera & 7 & & 1.00 & 195 & & -0.19 \\
\hline Hymenoptera n.i. & 4 & 4 & 0.64 & 91 & -0.08 & \\
\hline Braconidae & & & & 40 & -1 & \\
\hline Ichneumonidae & & & & 28 & -1 & \\
\hline Chalcididae & & & & 6 & -1 & \\
\hline Formicidae & 3 & 3 & 0.36 & 30 & 0.32 & \\
\hline Diptera & 87 & & 38.18 & 1320 & & 0.19 \\
\hline Diptera n.i. & 27 & 15 & 18.35 & 493 & 0.03 & \\
\hline Muscidae & 18 & 5 & 3.76 & 102 & 0.57 & \\
\hline Sarcophagidae & 2 & 2 & 0.40 & 174 & -0.65 & \\
\hline Calliphoridae & 1 & 1 & 0.04 & 56 & -0.49 & \\
\hline Culicidae & 7 & 6 & 1.70 & 216 & -0.24 & \\
\hline Psychodidae & 16 & 11 & 6.82 & 28 & 0.84 & \\
\hline Dolichopodidae & 1 & 1 & 0.04 & 172 & -0.81 & \\
\hline Simuliidae & 14 & 13 & 7.03 & 40 & 0.75 & \\
\hline Otitidae & & & & 1 & -1 & \\
\hline Tephritidae & 1 & 1 & 0.04 & 7 & 0.47 & \\
\hline Syrphidae & & & & 15 & -1 & \\
\hline Stratiomidae & & & & 1 & -1 & \\
\hline Tipulidae & & & & 15 & -1 & \\
\hline Arachnida & 13 & & 3,07 & 314 & & \\
\hline Acari & 7 & 6 & 1.62 & 230 & -0.27 & -0.27 \\
\hline Araneae & 6 & 6 & 1.45 & 84 & 0.16 & 0.16 \\
\hline Larvae n.i. & 2 & 2 & 0.5 & & 1 & 1 \\
\hline
\end{tabular}


TABLE 1 (Continued)

Comparison between $\mathrm{H}$. punctatus diet and environmental food resources

\begin{tabular}{|c|c|c|c|c|c|}
\hline \multirow{2}{*}{ Prey categories } & \multicolumn{3}{|c|}{ Frogs' diet } & \multirow{2}{*}{$\begin{array}{l}\text { Food availability } \\
\qquad \mathrm{N}\end{array}$} & Jacobs' index \\
\hline & $\mathrm{N}$ & $\mathrm{FO}$ & IRI\% & & orders' D \\
\hline Seeds & 25 & 9 & & & \\
\hline Total prey items & 213 & & & 4102 & \\
\hline
\end{tabular}

were the most important $(40.85 \%)$, followed by hemipterans $(22.07 \%)$, with the bulk of this order abundance represented by the family Lygaeidae (17.84\%). Homopterans (13.62\%) and coleopterans $(8.45 \%)$ also contributes importantly to frogs' diet (Table 1). In the environment, the most abundant items were also dipterans $(32.18 \%)$, followed by coleopterans $(15.53 \%)$, homopterans $(12.29 \%)$ and collembolans (12.04\%) (Table 1).

Diet composition analyzed at prey family level was quite similar between males and females, as indicated by a relatively high dietary overlap $\left(\mathrm{O}_{\mathrm{jk}}=0.5534\right)$, statistically higher than expected by chance (mean of simulated indexes: $\mathrm{O}_{\mathrm{jk}}=0.3091 ; \mathrm{p}[$ observed $\geq$ expected $]=0.044$; $\mathrm{p}[$ observed $\leq$ expected $]=0.956$ ). When analyzing diet at order level, the similarity between sexes was extremely high $\left(\mathrm{O}_{\mathrm{jk}}=0.9369\right)$ and statistically higher than expected by chance (mean of simulated indexes: $\mathrm{O}_{\mathrm{jk}}=0.3044 ; \quad \mathrm{p}[$ observed $\geq$ expected $]<0.0001$; $\mathrm{p}[$ observed $\leq$ expected $]=1$ ). The diet (at family level) did not differ between sexes neither in frequency of occurrence (observed $\chi^{2}=49.619$, mean of simulated indexes $=166.081, \quad \mathrm{p}[$ observed $\geq$ expected $]=1$; $\mathrm{p}[$ observed $\leq$ expected $]<0.0001) \quad$ nor in abundances of prey taxa (observed $\chi^{2}=68.969$, mean of simulated indexes $=244.843, \quad \mathrm{p}$ [observed $\geq$ expected $]=1$; $\mathrm{p}$ [observed $\leq$ expected $]<0.0001$ respectively).

With the exception of four Trichoptera $(1.88 \%)$ and two undetermined larvae $(0.94 \%)$, all prey categories found in $H$. punctatus gut contents were also found in sweep net samples, suggesting that food resources estimation was representative. Thirty two out of the sixty six determined arthropods categories in sweepnet samples were found in the guts of frogs. However, four insect orders sampled in the environment were not consumed by $\mathrm{H}$. punctatus, but, with the exception of Thysanoptera $(n=245,5.97 \%)$, none of them represented an important portion of environmental food resources (Protura: 0.02\%; Blattaria: 0.02\%; Neuroptera: $0.05 \%$ ) (Table 1).

Pianka's overlap index between frog diet and environmental food resources was medium $\left(\mathrm{O}_{\mathrm{jk}}=0.4739\right)$ but statistically higher than expected by chance (mean of simulated indexes: $\mathrm{O}_{\mathrm{jk}}=0.2296 ; \mathrm{p}[$ observed $\geq$ expected $]=0.017$; $\mathrm{p}[$ observed $\leq$ expected $]=0.983$ ).

Electivity index shows that $H$. punctatus forages hemipterans selectively over the observed environmental abundance $(Z=13.901$, $\mathrm{p}<0.001$ ), particularly because of the disproportional consumption of Lygaeidae ( $\mathrm{Z}=23.386$, $\mathrm{p}<0.001$ ) (Table 1). In contrast, frogs captured coleopterans relatively under their observed environmental abundance $(Z=-3.137, p<0.001)$, while homopterans were foraged almost proportionally to their observed environmental availability $(\mathrm{Z}=0.873, \mathrm{p}=0.383$ ) (Table 1). Dipterans were numerically and IRI the most important prey item and abundant food resource, and they were consumed scarcely over the observed environmental availability $(Z=2.736, p<0.003)$ 
(Table 1). Collembolans were a moderately abundant food resource (12.04\% of net sampled arthropods) and it appears that frogs avoided to forage on them $(Z=-4.914, p<0.001)$ (Table 1).

Plant seeds were found in $19 \%$ of the guts of frogs. Only five prey items had a greater FO than seeds and only three out of 12 prey orders were more abundant (Table 1).

\section{DISCUSSION}

The primary food resources for amphibians are insects and other arthropods like spiders and mites (Duellman \& Trueb 1986, Simon \& Toft 1991). In this work, we found that $H$. punctatus feeds principally on insects, being the more important orders Diptera, Hemiptera and Homoptera, and marginally on spiders and mites. The sympatric and cogeneric $H$. raniceps also was reported to predate mainly on insects over arachnids (Peltzer \& Lajmanovich 2001, Vaz-Silva 2004). Simon \& Toft (1991), analyzing mite-eating in frogs, found no specialization on Acari in family Hylidae. On the other hand, Maneyro \& Da Rosa (2004) found that Araneae showed the largest numerical proportion in the diet of $H$. pulchellus (also sympatric with $H$. punctatus), followed by Diptera, Hymenoptera and Coleoptera. As well, the diet of $\mathrm{H}$. albomarginatus was described to be compound by a greater proportion of arachnids, especially in the dry season (Santos et al. 2004). In other two Hypsiboas species, H. calcaratus and $H$. boans, spiders represented the secondary prey item by their volumetric contribution to frogs diet (Parmelee 1999). Parmelee (1999), also reported an "important volumetric contribution of Araneae to $H$. punctatus diet" in Peruvian Amazonian, but feeding analysis in the cited work was carried on just five frogs and only two spiders were found in anuran guts.

Comparisons of diet composition between males and females are not common in frogs feeding studies. This could be due to the relative difficulty of capturing females in many amphibian species. Particularly in H. punctatus, none work evaluates differences in diet between sexes (Parmelee 1999, López et al.
2002). In some amphibian species were this comparison has been explored, no differences between sexes have been found in the diet composition (Measey 1998, Hirai and Matsui 2000c), but in other anuran species, differences between males and females have been reported in proportions of several of their more important preys items (Filipello \& Crespo 1994, Kam et al. 1995). In the present study, we did not found statistical differences between the diet of males and females of $H$. punctatus and, although diet composition similarity was lower when overlap analysis was carried on prey family level than on order level, diet overlap was always high, and higher than expected by chance. Moreover, the reduced number of males in comparison to females analyzed could be limiting diet similarity results reliability, thus larger samples of males should be needed to strengthen these conclusions.

In this study we reported that nine out of forty seven $H$. punctatus specimens analyzed ingested seeds. Although consumption of plant material has been reported in studies on anuran feeding habits, plants are not regarded as an important resource in the anuran diet and some authors suggest the ingestion of plant parts as incidental (Korschgen \& Moyle 1955, Linzey 1967, Hedeen 1972, Mahan and Johnson 2007). According to Anderson et al. (1999), plant contents may help in the elimination of parasites and provide roughage to assist in grinding up arthropod exoskeletons. To explore any conclusion on the presence of seeds in $H$. punctatus gastrointestinal tracts more studies are required.

As Simon \& Toft (1991) argue in their work about diet specialization in small vertebrates, the notion of "specialized" versus "opportunistic" ("generalized") is often constrained by preconcepts on what certain taxa are "supposed" to eat. That is, as insectivores, frogs are already specialized; it is tempting to claim in this context that frogs show no selectivity within a range of prey that one expects them, a priori, to eat (Simon \& Toft 1991). This issue has been tackled in several feeding studies that evaluated the ant selectivity of a number of 
anurans based on the comparison of frogs' diet and environmental food resources (Toft 1980, 1981, Issach \& Barg 2002, Hirai \& Matsui 2000a, 2000b, López et al. 2007). These studies have arrived at diverse conclusions for different frog species. While López et al. (2007) found that the microhylid Elachistocleis bicolor was really selecting ants among a wider range of preys, Hirai \& Matsui (2000b) concluded that, although Gladirana rugosa consumes a large proportion of ants $(56.8 \%)$, this foraging pattern really shows a weak avoidance to this abundant prey since its proportion among environmental food resources was $81.3 \%$. To obviate food availability data may lead to an incorrect categorization of predators as specialist or generalist feeders.

In a previous work, López et al. (2002) found that $H$. punctatus feeds on dipterans in a similar proportion to our results, with a frequency of occurrence of $58 \%(\mathrm{FO}=56 \%$ in this work), and representing $57 \%$ of the total prey items computed ( $41 \%$ here). Without an estimation of environmental food resources, the high proportion of this prey item in gut contents may lead to the assumption that red spotted green frog is foraging selectively on dipterans. In the present study, the incorporation of food availability data allowed us to reevaluate this postulation. On one hand, although overlap index between frogs' diet and food resources was medium, it was statistically higher than expected by chance, meaning that this overlap is not the result of a strong selection of food resources consumed. On the other hand, prey electivity index values on the most important food items of $H$. punctatus showed a noticeable selection only for hemipterans, particularly family Lygaeidae, and slight sub-forage on coleopterans. However, the principal food item (numerically, by FO and IRI), dipterans, was consumed in a proportion only slightly over to the observed environmental abundance, thus indicating little selectivity for this prey item. Data on food resource availability is essential for the analysis of feeding ecology of frogs (or any other predator) because it provides critical information for a suitable categorization as generalist or specialist predators and the understanding of their role in trophic webs.

Finally, considering the wide range distribution of $H$. punctatus, it would be interesting to encourage new feeding studies of this species on other regions of South-America to elucidate if the foraging pattern here described is repeated in different populations and environments where different food resources are available.

\section{ACKNOWLEDGMENTS}

We thank María Gabriela Perotti, Felix Cruz and Gerardo Daniel López for the critical reading of the manuscript, their helpful suggestions and comments. This study was supported with a fellowship of Consejo Nacional de Ciencia y Tecnología (CONICET, Argentina).

\section{RESUMEN}

La falta de datos sobre la disponibilidad de recursos alimenticios en muchos trabajos sobre ecología trófica de anfibios ha llevado a una comprensión parcial de las estrategias alimentarias de este grupo. Este estudio evalúa la selectividad trófica de una población de Hypsiboas punctatus en una laguna del valle aluvial del río Paraná Medio en Argentina, y discute la importancia de los datos de disponibilidad de presas para interpretar las estrategias de alimentación de las ranas. Se analizaron los contenidos gastrointestinales de 47 adultos, y se compararon con la disponibilidad ambiental de presas, estimada mediante muestreo sistemático del micro-hábitat de forrajeo de los anuros. Se identificaron 33 categorías de presas. Las más importantes fueron dípteros, hemípteros, homópteros y coleópteros. Se encontró una elevada similitud entre la dieta de machos y hembras, y no se hallaron diferencias significativas en su composición. Los recursos alimenticios más abundantes fueron los dípteros, coleópteros, homópteros y colémbolos. La superposición de nicho trófico fue media (índice de Pianka) pero significativamente más elevada que la esperada por azar. H. punctatus consumió dípteros en una proporción levemente superior a su disponibilidad ambiental (índice de selectividad de Jacobs). La estrategia de depredación de $H$. punctatus se ajusta mejor a una táctica generalista, ya que su principal ítem presa y algunos ítems secundarios fueron capturados en proporciones similares a su disponibilidad ambiental, y solo una porción reducida de su espectro de recursos tróficos fue consumida selectivamente. Estos resultados evidencian la importancia de incluir los datos de disponibilidad de recursos en los estudios de alimentación para lograr un mejor entendimiento de la ecología trófica de los anfibios. 
Palabras clave: Hypsiboas punctatus, selectividad trófica, recursos alimenticios, dieta, anuros.

\section{REFERENCES}

Anderson, A.M., D.A. Haukos \& T.J. Anderson. 1999. Diet composition of three anurans from the Playa Wetlands of Northwest Texas. Copeia 1999: 515-520.

Burton, T.M. 1976. An analysis of feeding ecology of the salamanders (Amphibia, Urodela) of the Hubbard Brook Experimental Forest, New Hampshire. J. Herpetol. 10: 487-204.

Caldwell, J.P. \& L.J. Vitt. 1999. Dietary asymmetry in leaf litter frogs and lizards in a transitional northern Amazonian rain forest. Oikos. 84: 383-397.

Cott, H.B. 1932. On the ecology of tree-frogs of the Lower Zambesi Valley, with special reference to predatory habits considered in relation to the theory of warning colours and mimicry. Proc. Zool. Soc. Lond. 1932: 471-541.

Cott, H.B. 1934. On the ecology of Hyla arborea var. meridionalis in Gran Canaria, with special reference to predatory habits considered in relation to the protective adaptations of insects. Proc. Zool. Soc. Lond 1934: 311-331

Drago, E.C., I.E. de Drago, O.B. Oliveros \& A.R. Paira. 2003. Aquatic habitats, fish and invertebrates assemblages of the Middle Paraná River. Amazoniana. 17: 291-341.

Duellman, W.E. \& L. Trueb. 1986. Biology of Amphibians. McGraw-Hill, New York, New York, USA. 670p.

Duellman, W.E. \& M. Lizana. 1994. Biology of a sit-andwait predator, the leptodactylid frog Ceratophrys cornuta. Herpetologica, Emporia. 50: 51-64.

Dunham, A.E. 1983. Realized niche overlap, resource abundance, and intensity of interspecific competition: pp. 261-280, In: R.B. Pianka \& T. Schoener (eds.), Lizard Ecology: studies of a model organism. Harvard, Massachussetts, USA.

Filipello, M.A. \& F.A. Crespo. 1994. Alimentación en Melanophryniscus stelzneri (Anura: Bufonidae). Cuad. de Herp. 8: 18-24.

Frost, S.W. 1924. Frogs as insect collectors. J. N. Y. Entomol Soc. 32:174-185.

Frost, S.W. 1935.The food of Rana catesbeiana. Copeia. 1935: $15-18$
Gallardo, J.M. 1987. Anfibios Argentinos. Guía para su identificación. 83p.

Gallardo, J.M. \& E. Varela de Olmedo. 1992. Anfibios de la República Argentina: Ecología y comportamiento. Fauna de agua dulce de la República Argentina. PROFADU (CONICET), La Plata, 41(1): 116 pp.

Gotelli, N.J. \& G.L. Entsminger. 2003. EcoSim: Null Models Software for Ecology, Version 7. Acquired Intelligence Inc. \& Kesey-Bear, Burlington, Vermont, USA. http://www.garyentsminger.com/ecosim/index. htm. Accessed on 18 June 2008.

Hamilton, W.J. Jr. 1930. Notes on the food of the American toad. Copeia. 2: 45.

Hamilton, W.J. Jr. 1948. The food and feeding behavior of the green frog Rana clamitans Latreille in New York State. Copeia. 1948: 203-207.

Hedeen, S.E. 1972. Food and feeding behavior of the mink frog, Rana septentrionalis Baird, in Minnesota. Am. Midl. Nat. 88:291-300.

Hirai, T. 2004. Diet composition of the Indian rice frog, Rana limnocharis, in the floodplain of the Kizu River, Japan. Herpetol. J. 14: 149-152.

Hirai, T. \& M. Matsui. 2000a. Ant specialization in diet of the narrowmouthed toad, Microhyla ornata, from Amamioshima Island of the Ryukyu Archipelago. Curr. Herpetol. 19: 27-34.

Hirai, T. \& M. Matsui. 2000b. Myrmecophagy in a Ranid Frog Rana rugosa: Specialization or Weak Avoidance to Ant Eating? Zool. Sci. (Tokyo). 17: 459-466.

Hirai, T. \& M. Matsui. 2000c. Feeding Habits of the Japanese Tree Frog, Hyla japonica, in the Reproductive Season. Zool. Sci. 17: 977-982

Hirai, T. \& M. Matsui. 2001a. Food habits of an endangered Japanese frog, Rana porosa brevipoda. Ecol. Res. 16: 737-743.

Isacch, J.P. \& M. Barg. 2002. Are bufonid toads specialized ant-feeders? A case test from the Argentinian flooding pampa. Journal of Natural History. 36: 2005-2012.

IUCN, Conservation International, and NatureServe. 2006. Global Amphibian Assessment. <www.globalamphibians.org > . Accessed on 18 June 2008.

Jacobs, J. 1974. Quantitative measurement of food selection: a modification of the forage ratio and Ivlev's electivity indices. Oecologia. 14: 413-417. 
Kam, Y.C., C.S. Wang \& Y.S. Lin. 1995. Reproduction and diet of te brown frog Rana longicrus in Taiwan. Zool. Stud. 34: 193-201.

Klimstra, W.D. \& C.W. Meyers. 1965. Foods of the toad Bufo woodhousei fowleri Hinckley. Transactions of the Illinois State Academy of Science. 58: 11-26.

Korschgen, L.J. \& D.L. Moyle. 1955. Food habits of the bullfrog in central Missouri farm ponds. Am. Midl. Nat. 54: 332-341.

Krebs, J.R. 1978. Optimal foraging: decision rules for predators, p 23-63. In: J.R. Krebs \& N.B. Davies (eds). Behavioural Ecology: An Evolutionary Approach. Oxford: Blackwell, London, England.

Lajmanovich, R.C. 1995. Relaciones tróficas de bufonidos (Anura, Bufonidae) en ambientes del Río Paraná, Argentina. Alytes. 13: 87-103

Lajmanovich, R.C. 1996. Dinámica trófica de jóvenes de Leptodactylus ocellatus (Amphibia: Anura), en una isla del Paraná, Argentina. Cuad. Herpetol. 10: 11-23.

Lescure, J. 1971. L'álimentation du crapaud Bufo regularis Reuss et de la grenouille Dicroglossus occipitales (Gunther) au Senégal. Bulletin del'Institut Fondamental d'Afrique Noire. 33: 446-466.

Lieberman, S.S. 1986. Ecology of the leaf litter herpetofauna of a Neotropical rain forest: La Selva, Costa Rica. Acta Zool. Mex. 15: 1-72.

Linzey, D.W. 1967. Food of the leopard frog Rana pipiens, in central New York. Herpetologica. 23: 11-17.

López, J.A., M.P. Perltzer \& R.C. Lajmanovich. 2002. Hyla punctata $(\mathrm{NCN})$. Diet. Herpetol. Rev. 33: 125-126.

López, J.A., M.P. Perltzer \& R.C. Lajmanovich. 2003. Physalaemus riograndensis $(\mathrm{NCN})$. Diet. Herpetol. Rev. 34: 360

López, J.A., M.M. Arias, M.P. Perltzer \& R.C. Lajmanovich. 2005a. Dieta y variación morfométrica de Leptodactylus ocellatus (linnaeus, 1758) (anura: leptodactylidae) en tres localidades del centro-este de argentina. Bol. Asoc. Herpetol. Esp. 16: 32-39.

López, J.A., M.P. Perltzer \& R.C. Lajmanovich. 2005b. Dieta y solapamiento del subnicho trófico de nueve especies de leptodactílidos en el Parque General San Martín (Argentina). Rev. Esp. Herpetol. 19: 19-31.

López, J.A., R. Ghirardi, P.A. Scarabotti \& M.C. Medrano. 2007. Feeding ecology of Elachistocleis bicolor in a riparian locality of the middle Paraná River. Herpetol. J. 17: 48-53.

Mahan, R.D. \& J.R. Johnson. 2007. Diet of the Gray Treefrog (Hyla versicolor) in Relation to Foraging Site Location, J. Herpetol. 41: 16-23.

Maneyro, R. \& I. da Rosa. 2004. Temporal and spatial changes in the diet of Hyla pulchella (Anura, Hylidae) in southern Uruguay. Phyllomedusa 3: 101-113.

Maneyro, R., D.E. Naya, I. da Rosa, A. Canavero \& A. Camargo. 2004. Diet of the South American frog Leptodactylus ocellatus (Anura, Leptodactylidae) in Uruguay. Iheringia Ser. Zool. 94: 57-61.

Measey, G. J. 1998. Diet of feral Xenopus laevis (Daudin) in South Wales, U. K. J. Zool. Lond. 246: 287-298.

Neiff, J.J. 2001. Biodiversity in some tropical wetlands systems of South America, pp 157-186. In: B. Gopal, W.J. Junk \& J.A. Davis (eds). Biodiversity in wetlands: assessment, function and conservation. Blackhuys, Leiden, The Netherlands.

Parmelee, J.R. 1999. Trofhic ecology of a tropical anuran assemblage. Scientific Papers. Natural History Museum, The University of Kansas. 11: 1-59.

Peltzer, P.M. \& R.C. Lajmanovich. 2001. Hyla raniceps (NCN). Diet. Herp. Rev. 32: 247-248.

Pianka, E.R. 1974. Niche overlap and diffuse competition. Proc. Natl. Acad. Sci. U. S. A. 71: 2141-2145.

Pianka, E.R. 1986. Ecology and Natural History of Desert Lizards. Princeton, New Jersey, U.S.A. 150-167.

Pinkas, L., M.S. Oliphant \& Z.L. Iverson. 1971. Food habit of albacore bluefin, tuna and bonito in California water. California Department of Fishing Game. Fish Bull. 152: 1105 .

Santos, E.M., A.V. Almeida \& D. Vasconcelos. 2004 Feeding of six anuran (Amphibian: Anura) species in a rainforest fragment in Northeastern Brazil. Iheringia, Ser. Zool. 94: 433-438.

Simon, M.P. 1982. The evolution and ecology of parental care in a terrestrial breeding frog from New Guinea. Ph.D. Thesis, University of California, Davis, USA.

Simon, M.P \& C.A. Toft. 1991. Diet Specialization in Small Vertebrates: Mite-Eating in Frogs. Oikos. 61: 263-278. 
Smith, H.M. 1950. Handbook of Amphibians and Reptiles of Kansas. - University of Kansas, Museum of Natural History. Mac-Millan, New York, USA.

Sokal, R.R. \& F.J. Rohlf. 1995. Biometry: The principles and practice of statistics in biological research. Third edition. Freeman. 887 p.

Stephens, D.W \& J.R. Krebs. 1986. Foraging Theory. Princeton: Princeton, New Jersey, USA. 240 p.
Toft, C.A. 1980. Feeding ecology of thirteen syntopic species of anurans in a seasonal tropical environment. Oecologia. 45: 131-141.

Toft, C.A. 1981. Feeding ecology of Panamanian litter anurans: Patterns in diet and foraging mode. J. Herpetol. 15: 130-144.

Vaz-Silva, W. 2004. Hyla raniceps (Chaco Treefrog). Diet. Herp. Rev. 35: 159. 